\title{
The Application of Task-based Writing and Traditional Writing on the Development of Reading Comprehension of EFL Advanced Iranian Learners
}

\author{
Seyed Hamed Seyedi (Corresponding Author) \\ Dept. of English, Abadeh Branch, Islamic Azad University, Abadeh, Iran \\ Tel: 98-912-219-7099Ｅ-mail: hamed.seyedi@yahoo.com
}

Ali Akbar Khomeijani Farahani

Dept. of English, University of Tehran, Tehran, Iran

Tel: 98-912-159-4413Ｅ-mail: farahani@ut.ac.ir

Received: March 5, 2014 Accepted: March 20, 2014 Published: March 20, 2014

doi:10.5296/ijele.v2i1.5330 URL: http://dx.doi.org/10.5296/ijele.v2i1.5330

\begin{abstract}
Every single teaching method has its own merits and demerits; however, teachers typically select a method which they deem suitable. Task-based language teaching, a learner-centered method, advocates the shift from teacher dependence to learner independence. This study was an attempt to find out if traditional writing makes a significant contribution to the development of reading comprehension. It also concentrated on the usefulness of performing writing tasks on the development of reading comprehension. The participants were 60 female advanced EFL learners chosen from among 100 learners, randomly assigned into two groups of 30 learners. During the treatment period, first-group participants received task-based writing instruction while second-group participants received instructions through traditional methods. The analyzed results clearly demonstrated the contribution of task-based writing to the development of reading comprehension of EFL advanced Iranian learners. The findings also showed that traditional writing instruction was not a good means of improving reading comprehension.
\end{abstract}

Keywords: Task-based writing, Traditional writing, Reading comprehension 


\section{Introduction}

In traditional learning environments, like those of grammar translation and audio-lingual, language is taught to a group of foreign or second language learners with minor focus on form and major focus on forms. In such cases, the focus is on the language itself, rather than on the information conveyed by the language or the way it is used and processed. The teacher should ensure that students learn the new vocabulary and grammatical rules of the new language (Buykkarci, 2010).

According to Benevides and Valvona (2008), task-based language teaching (TBLT) furnishes the basis for both instruction and assessment. Using tasks as the stepping-stone of syllabus design allows teachers to both sequence lessons and assess their outcomes, while at the same time provides authentic parameters within which students will be able to communicate with each other for a purpose. Most importantly, it paves the way for focusing on what students are saying to one another, rather than on how they are saying it. A task might be short (e.g., ordering a sandwich by telephone) or long (e.g., organizing and publishing a book), but the tasks are always equipped with a clear and practical outcome.

Task-based instruction has its own advantages and disadvantages. It is beyond doubt that advantages outweigh disadvantages. TBI is appropriate for all ages and backgrounds, especially young learners. All children have acquired their L1 in a contextualized setting, and have acquired grammar and structure inductively. Their focus is on meaning, not form. A special consideration for these learners is that their language skills are still developing and teachers must be careful to create level-appropriate tasks for the learners (Bourke, 2006). Task-based instruction can also be used to teach content and language, can be integrated with more traditional teaching methods, can create motivation due to tasks being relevant and immediate, and can be a useful approach for learners who do not have a predilection for more traditional types of classroom learning or where teachers have little autonomy over their lesson planning (Krahnke, 1987).

Krahnke (1987) tries to shed light on the disadvantages as well. He believes that TBI requires a high level of creativity and initiative on the part of the teacher. There are some resources in the ESL field for TBI tasks, but it remains on the teachers to create meaningful and authentic lessons for their particular students' needs. In an EFL context, there is a bigger challenge since comprehensible target language input is restricted. Krahnke (1987) places emphasis on the use of authentic materials and communication with native speakers. Another drawback of TBI is that learners may prefer more traditional types of teaching. TBI relies mainly on students' motivation and commitment. Students, who are used to a teacher-centered classroom with minimum interaction on their part, might feel lethargic, and even unwilling to complete the tasks, especially real-life tasks. The other difficulty is that teachers will not be able to evaluate students' performance in TBI unless a specific rubric for assessment is created (Krahnke, 1987).

In weighing up both sides of the above-mentioned argument regarding advantages and disadvantages of TBI; it is advisable to integrate this method with the more traditional methods that include a focus on language forms. Language acquisition is a complicated 
process, and TBI is a good means to integrate meaning and form.

With regard to the above-mentioned points, the following research question was raised:

Is task-based writing more effective than traditional writing on the development of reading comprehension among EFL advanced Iranian learners?

\section{Review of the Related Literature}

\subsection{The Shift toward Communicative Language Teaching: A Historical Overview}

For many years the dominant method of language instruction was the grammar-translation method. This method owes much of its origin to the teaching of the nineteenth century and was widely used for the first half of the last century to teach modern foreign languages (Richards \& Rodgers, 2001). Textbooks primarily contained lists of vocabulary and explanations. Generally, students immersed themselves in translation tasks. Minor oral proficiency would be gained from the grammar-translation method, and learners often were expected to travel to native countries to become a fluent speaker (Richards \& Rodgers, 2001).

Willis (2004) asserts that the shortcomings of the behaviorist audiolingual method of language teaching of the 1960s in enabling learners to communicate in the target language led to the emergence of CLT with a shift of focus on communication. Although spoken language was the number one priority of the audiolingual method, the adopted approach toward this goal was drastically flawed. Audiolingual method was based on the assumption that language learning is a process of habit formation and automatization i.e. learners could use language patterns accurately both inside and outside the classroom contexts provided that language patterns' were presented, imitated, and practiced intensively (Willis, 2004).

Approaches to language teaching and learning could be seen on a continuum in which the two extremes are form-based and meaning-based. Form-based approaches rest on the belief that language should be introduced or presented to learners piece by piece as a formal system. When they have understood how a particular linguistic form is structured and used they can begin to use it for communication. Meaning-based approaches, however, make the assumption that learners develop a language system by their own attempts to use the language. The teacher's role is to provide opportunities for meaningful activities, to expose learners to language which would provide appropriate comprehensible input for their system, enabling natural learning, and to encourage learners to look critically at that input and learn from it, like finding a new way of expressing a specific meaning (Willis \& Willis, 2009).

\subsection{Task-based Language Teaching (TBLT)}

With the emergence of the communicative language teaching approach in the early 1980 s and its emphasis on learners' communicative abilities over the last two decades, the term task-based language teaching (TBLT) came into existence in the realm of second language acquisition with respect to developing process-oriented syllabuses and designing communicative tasks to foster learners' actual language use. Within the different interpretations of TBLT related to classroom practice, recent studies shed light on three recurrent features: TBLT is in harmony with a learner-centered educational philosophy (Ellis, 
2003); it is equipped with goal, procedure, and specific outcome (Skehan, 1998); it sides with content-oriented meaningful activities (Littlewood, 2004).

Task-based language teaching and syllabus, which owe their origins to research on second language acquisition (SLA), have attracted some researchers and curriculum developers in second/foreign language instruction as a result of widespread interest in the views of language and communicative language teaching. Due to the existence of such views, some practitioners and researchers suggested that task should be the key unit within the syllabus. TBL stems from the more general notion of communicative language teaching (CLT). It is supported by the process-oriented view of language learning where meaningful communicative tasks enhance L2 learning. Proponents of TBLT argue that the use of grammar-focused teaching activities in many language classrooms does not reflect the cognitive learning processes employed in naturalistic language learning settings outside the classroom. So they believe in better contexts for the activation of learning processes (Nahavandi \& Mukundan, 2012).

In spite of the growing interest in TBLT over recent years, its usefulness and effectiveness in teaching forms have raised doubts among some teachers and researchers. For example, as one of the major problems that learners may encounter by engaging in TBLT, Sato (2010) explains that "the effectiveness of TBLT, especially in teaching grammar (form), can be questioned" (p. 191). And Kess (1992) adds that learners place emphasis on communicating meanings, but are not necessarily worried about the exact form that they use.

Considering the fact that language acquisition is highly affected by the complex interactions of a number of variables, namely materials, activities, and corrective feedback, TBLT has a profound impact on these variables. It is beyond question that TBLT deals with natural sources of authentic material, ideal situations for communicative activity, and corrective feedback allowing for much greater opportunities for language use. In an Asian EFL environment where learners are restricted in their accessibility to use the target language on a regular basis, it is of paramount importance to provide learners with real opportunities to be exposed to language use in the classroom (Jeon \& Hahn, 2009).

\subsection{Theoretical Framework of Task-based Learning}

Based on the explanation by Fotos (2002), the theoretical assumption for task-based approaches is that interaction is the stepping-stone to language acquisition and that both learner comprehension and production play major roles in interaction (Ellis, 1994, 1997; Nunan, 1993). As Fotos (2002, p.138) comments, "task can supply the learner with target language input that is rich in communicative usages of problematic target structures, and task performance provides opportunities for the type of learner interaction suggested to promote language acquisition; that is opportunities to produce the target language and receive feedback on the productions" (Foto, 2002, p.138). With the help of such feedback, "it enables learners to notice the gap between the target language they want to produce and the limitation of their current interlanguage" (Fotos 2002, p. 138).

Engaging learners in a variety of tasks is one of the challenges of task-based learning. 
Learners have many pedagogical needs that require a different approach to teaching. For instance, they need to be engaged in psycholinguistic and metalinguistic processes such as repetition, hypothesization, and conceptualization of rules (Nunan, 2004). For this reason, Nunan (2004) draws a distinction between two kinds of tasks: real-life tasks and pedagogic tasks. Real-life tasks are used to emphasize those skills that learners need to have in order to function in the real world. Such tasks share similarity with authentic task behavior, and their primary concern is to achieve an end product.

\subsection{Definition of Task}

Definition of a task has been one of the areas in research and language teaching that has baffled the practitioners from its terminology to its scope and its differentiation from an exercise, an activity, or drill. According to Crookes (1986), there is no clear agreement as to what constitutes a task and there is no consistency regarding the description the different devices for eliciting learner language.

There are two main definitions of tasks: the broad definition and the narrow definition. A broad definition according to Long (1985, cited in Ellis, 2003, p. 2), "includes tasks that require language", for instance making an airline reservation. And a narrow definition "define task as an activity that necessarily involves language".

\subsection{Critical Features of a Task}

A task according to Ellis (2003) has the following six features:

1. "A task is a workplan".

2. "A task involves a primary focus on meaning".

3. "A task involves real-world processes of language use".

4. "A task can involve any of the four language skills".

5. "A task engages cognitive processes".

6. "A task has a clearly defined communicative outcome" (pp. 9-10).

\subsection{Task vs. PPP (Presentation, Practice, Production)}

Skehan (1996) makes a distinction between PPP (presentation-practice-production) as a traditional and form-focused language teaching approach, and task-based approach as meaning-focused approach in the realm of second language acquisition through natural language learning processes, and a series of systems or interlanguages.

According to Harmer (2007, cited in Carless, 2009), PPP has been taught to pre-service teachers as an effective teaching procedure from the 1960s onwards. The infrastructures of PPP, as Byrne (1986) puts, are that the teacher presents new language items; the learners practice the items via drills, silent talk, and choral repetition to produce the language for themselves, to express what they want to say rather than what the teacher has directed them to. PPP is considered an approach which rigidly controls learners' language, learners will 
learn what is taught in the order in which it is taught, and keeps the authority of the teacher. Skehan (1996) makes a comparison between the two approaches:

A PPP Approach looks on the learning process as learning a series of discrete items and then bringing these items together in communication to provide further practice and consolidation. A task-based approach sees the learning process as one of learning through doing - it is by primarily engaging in meaning that the learner's system is encouraged to develop. (p. 20)

Skehan (1998) is critical of PPP as it is believed that most language leaning methods, based on this approach, are associated with relative failure, claiming only the talented learners will be highly proficient. Therefore, instead of PPP, he supports a task-based approach in terms of its role as a means for classroom interaction which promotes language learning rapidly and efficiently.

\subsection{Task-based Writing (TBW)}

Task-based writing is one of the most important and inseparable part of task-based instruction. Cabral (2003) asserts that writing is a social act. Even when the writers are in the EFL language classroom context, their texts not only show their capability to solve a problem, but also their texts show their awareness of their own communicative goals. Thus, TBI/FFI which shows teacher-planned interactions and discussions in class can lead to language learning; consequently, the learners would be able to notice their syntactic errors that cause communication problems. It is this noticing that lays an infrastructure for awareness and subsequent language proficiency (Cabral, 2003).

Task-based writing, to Tilfarioglu and Basaran (2007), is a good means of integrating the four skills and can enhance effective language learning because the prime purpose is to produce something, reach a conclusion, and create a whole picture of something within a pre-set frame. Such activities are multi-faceted; they are done to improve the learners writing skill, and are expected to help to improve the other skills, as well.

\subsection{Traditional Writing}

In the 1950s and 1960s, the fundamental focus of rhetoric and composition was on analyzing literature and the writing style of learners. Writing assignments were mainly related to the discussion of literary works, and writing pedagogy mostly targeted the grammar and rhetorical structure (Hinkle, 2002).

Instruction and mechanics have been the traditional phases of writing instruction in many English classrooms. However, some current research suggests that the effect of instruction to grammar is insignificant on students' writing skill. As a matter of fact, since teaching grammar is time-consuming, and the class time could be spent on writing itself, and since its usefulness is unclear to many students, the effect of such teaching maybe even harmful (Hinkle, 1994). Writing teachers should raise students' awareness of the sophisticated linguistic and rhetorical skills they already possess, and then the primary concern should be on designing classroom work to unable students to control their skills with effectiveness. If 
students are forced to focus on the structural accuracy of their language use, it gets in the way of ideas often students either won't write anything significant; or they will produce grammatically correct but empty and flawful compositions (Hinkle, 1994). He takes his claim to the next stage by saying that writing requires practice; we cannot simply teach all about writing and the language rules without letting students' practice; we cannot teach about swimming without making the students get into water and swim. According to him, the main purpose of writing is communication (to write about something, in some medium, for some purpose, and to someone), and the emphasis of writing instruction must be laid upon effectiveness of texts and not correctness of units of the texts.

\subsection{Writing and Reading Processes: Similarities and Dissimilarities}

Constructivist theory asserts that writing and reading are both meaning-focused activities (Gregg \& Steinberg, 1980). When people write and read, meaning is continually formed. The mind anticipates, looks back, and forms relatively short impressions that change and grow as meaning develops (Langer, 1984). He goes on by mentioning that language, syntax, and structure are actively engaged as texts-in the-head and texts-on-paper develop. Since writing and reading require the development of meaning, both were conceptualized as written activities in the sense that both have planning, generating and revising meaning, which continually take place throughout the meaning-making process as a person's text world or envisionment grows.

From this point of view, some scholars speak of the writer as a reader and the reader as a writer (Graves \& Hansen, 1983; Smith, 1983). According to Smith (1983) reading like a writer allows one to actually become a writer. When reading like a writer, besides making meaning of the text, the reader understands and learns from the author's style, use of conventions and the like. When reading like a writer, the reader utilizes the author's text as a model for texts that he or she might eventually produce.

Tierney and Pearson (1983) argue that both readers and writers compose meaning. They describe the essential features of the effective composing process as follows: planning, drafting, aligning, revising, and monitoring. Additionally, they see these acts of composing as involving continuous, recurring, and recursive transactions among readers and writers, their respective inner selves, and their perceptions of each other's goals and desires. They distinguish their conception from earlier notions of reading and writing relationships in a variety of ways including treating the two domains as multi-modal processes and considering the inner as well as social selves of the writer and reader.

Researchers have also mentioned some differences between writing and reading. In her study regarding reading and writing, Langer (1986) assets that while reading and writing are cognitively related with regard to meaning making, they are markedly different with regard to activity, strategy and purpose. These two skills also vary across ages with regard to the variety of approaches that learners adopt and the behaviors they exhibit while reading or writing.

Langer (1986) develops a procedure for analyzing the knowledge sources, reasoning operations, monitoring behaviors and specific strategies in the course of meaning construction before, during and after reading and writing on the 3rd, 6th and 9th graders' reading and writing 
of stories and reports. The results of her study show that although the same reasoning behaviors are exhibited when reading and writing for meaning, the patterns of each category reveal differences between writing and reading. Generally, the study identified differences in behaviors and their frequency of use in response to the nature of the task.

While reading and writing, students' main concern is found to be with the meanings they are trying to make. There are also consistent ways to focus on ideas, content, product, and refinement of meaning. The mentioned structures and strategies change in similar ways as the language user mature. Nonetheless, underlying this general focus are such differences as bottom-up issues such as mechanics, syntax, text, and lexical choices when writing in comparison with reading (Langer, 1986). Moreover, when students write they are more aware of and concerned with the strategies they use to get to meaning. During writing, they are more concerned with setting goals and sub-goals. While reading, however, they focus more on content and validation of the text they are developing (Langer, 1986).

Langer and Falihan (2000) claim that the research on reading and writing processes indicates that writing and reading are closely related activities of language and thought that are shaped through use. The structures and strategies that writers and readers adopt to organize, remember, and present their ideas are normally the same in writing and reading. However, the structure of the message and the strategies used to formulate and organize it are driven by purpose and therefore different (Langer \& Falihan 2000).

\section{Method}

\subsection{Participants}

The participants of the present study were 60 female advanced EFL learners who were selected from 100 learners, were randomly assigned into two groups of 30 learners, and received ten sessions of instruction (treatment) of English writing class at Zabansara institute in Tehran. The average age of the participants was about 24, and they shared the same language proficiency level. They were EFL learners of English and had been studying at the same Institute for about three years. The participants in the first group comprised the experimental group (task-based writing) and the participants in the second group comprised the control group (traditional writing).

\subsection{Instruments}

In this study, multiple instruments were used to increase the reliability of data. A standard version of Paper-based TOEFL (PBT) was used. The test which was administered had 3 sections (structure, written expression, and reading comprehension):

Section 1: Structure (15 items)

Section 2: Written expression (25 items)

Section 3: Reading comprehension (50 items)

Before administrating the test (TOFEL) to main groups, the test was piloted in order to have the essential modifications. Its reliability was ensured through pilot-testing done with a group 
of 30 learners. The reliability index was 0.76 . The reading section of the homogeneity test (Paper-based TOEFL) was used before and after the treatment (as pretest and post-test) to determine the participants' reading comprehension changes, if any.

The tasks, used during the treatment period in the experimental group, were selected from First Certificate Gold Practice Exams (Paran, 1996) and also IELTS writing tasks because they are mainly based on the principles and procedures of task-based language teaching.

The control group received instruction through traditional methods and techniques as was planned beforehand.

\subsection{Procedure}

Several procedures were used to achieve the purposes of this study. First, the sampling was done and then the homogeneity test (Paper-based TOEFL) was administered to assess the participants' language proficiency level. The 60 homogeneous participants (selected from 100 participants, and gained at least the 70 percent of the total score) were divided randomly into two groups of 30 and both groups received the pre-test (reading section of the above-mentioned Paper-based TOEFL Test). By the beginning of the treatment period, task-based writing instruction was used in the first group (experimental group); traditional writing was used in the other group (control group).

The treatment that the experimental group received was in the form of several task-based writing activities used in FCE and IELTS exams, namely graph description writing, argumentative essay writing, email writing, report writing, and review writing.

During the treatment period, the participants in the experimental group were taught the above-mentioned task-based writing activities in ten sessions (two sessions were allocated to each activity). They were asked to write two compositions every session on the appointed task-based writing activities. For example, in the first session, they were asked to describe a graph before knowing the steps and tips of writing a graph description. After teaching the participants the steps and tips of writing a graph description, they were asked to write another composition on the above-mentioned topic, both compositions were scored by two qualified raters, who were both MA students and were equipped with eight years of teaching experience based on a writing rating scale, in order to avoid the subjectivity of scoring.

The previously mentioned process was used for other task-based writing activities (argumentative essay writing, email writing, and report writing). Owing to the once-in-a-week class attendance of the participants, they had quite good enough time to practice throughout the week.

In short, each session of the treatment period was broken down into three phases. In the first phase (pre-task stage) the participants were introduced to the framework of the writing tasks; their prior knowledge was activated via questions and answers. In the second phase (during-task) the learners received a reading text, which shared a similarity of topic with the newly taught writing framework, and were required to analyze that with the help of the teacher. This process was followed by the participants' own compositions on the appointed 
writing framework with the purpose of integrating writing and reading skills. Because task-based writing is a good means of the integration of skills, the researcher provided the participants with aural materials which were related to the taught writing material. In task-based language teaching the emphasis lies in assessment, and both self and peer-assessments are welcome. In so doing, learners were assigned to groups of two or three members to negotiate and discuss their answers with the help of the teacher's ongoing feedback. In the final stage (post-task) after task completion (on the part of the learners) the learners were asked to proofread their compositions on the basis of an editing checklist. In task-based language teaching the learners must receive feedback on the location of errors but must not be provided with the correct form; it enables the participants to complete the tasks collaboratively as well as individually.

The participants in the second group (traditional writing) did not receive any particular treatment because they comprised the control group. The linguistic features were highlighted through teaching the grammatical structures of the target language explicitly to the learners, plus analyzing literary texts, practicing language points, imitating model texts, writing with the application of decontextualized words, and analyzing the students' writing style. The course, which lasted for ten weeks and during which the control group was taught three hours a week. The primary focus was on forms, and the negotiation of meaning did not play a major role in this approach to writing.

After the treatment, the pretest (reading section of the TOFEL Test) was administered as post-test to both groups of the students to see whether there was any significant improvement in the reading comprehension ability of the participants in both groups.

\section{Results and Discussion}

\subsection{Data Analysis}

This section is devoted to a description of the analyses of the collected data. Therefore, it seems reasonable to restate the purpose and the questions of this study. As it was mentioned before, this research was concerned with one problem: the effect of task-based writing and traditional writing on the development of reading comprehension of among EFL advanced Iranian learners.

The following null hypothesis was therefore stated:

Null Hypothesis: Task-based writing is not more effective than traditional writing on the development of reading comprehension among EFL advanced Iranian learners.

\subsubsection{Pretest of Reading Comprehension}

After gathering the data, the SPSS software was used for analyzing the data. To achieve the purpose of the study, it was essential to make sure that the data were normally distributed, i.e. they did not contradict the assumptions of normal distribution.

An independent t-test is run to compare the mean scores of the experimental and control groups on the pretest of reading comprehension prior to the administration of the task-based 
writing and traditional writing.

Table 1. Pretest of reading comprehension by groups

\begin{tabular}{|ll|c|c|c|c|}
\hline & & & & & \\
Groups & & $\mathrm{N}$ & Mean & Std.Deviation & $\begin{array}{c}\text { Std. Error } \\
\text { Mean }\end{array}$ \\
\hline Pretest & Task-based Reading & 30 & 23.0333 & 5.41698 & .98900 \\
& Traditional Reading & 30 & 22.1667 & 6.43312 & 1.17452 \\
\hline
\end{tabular}

As displayed in table 1 the mean scores for the experimental and control groups on the pretest of reading comprehension are 23.03 and 22.16 .

Table 2 is related to the pretest of reading comprehension of both experimental group and control group.

Table 2. Independent t-test pretest of reading comprehension by groups

\begin{tabular}{|c|c|c|c|c|c|c|}
\hline \multirow{2}{*}{} & \multicolumn{2}{|c|}{$\begin{array}{c}\text { Levene's Test for } \\
\text { Equality of Variances }\end{array}$} & \multicolumn{3}{|c|}{ t-test for Equality of Means } \\
\cline { 2 - 8 } & $\mathrm{F}$ & Sig. & $\mathrm{t}$ & $\mathrm{Df}$ & $\begin{array}{c}\text { Sig. } \\
(2 \text {-tailed) }\end{array}$ & $\begin{array}{c}\text { Mean } \\
\text { Differe } \\
\text { nce }\end{array}$ \\
\hline Pretest Equal variances assumed & .752 & .389 & .564 & 58 & .575 & .86667 \\
Equal variances not assumed & & & .564 & 56.336 & .575 & .86667 \\
\hline
\end{tabular}

The results of the independent $\mathrm{t}$-test $(\mathrm{t}=0.564)$ represents a weak effect size and indicates non-significant difference between the mean scores of the two groups on the pretest of reading comprehension. Thus it can be concluded that the experimental and control groups were homogenous in terms of the reading comprehension ability prior to the administration of task-based writing and traditional writing.

It should be noted that the assumption of homogeneity of variances is met. As displayed in table 2 the Levene's F-value is not significant $(\mathrm{F}=0.75)$. That is why the first row of table 2, i.e. "Equal variances assumed" is reported.

\subsubsection{Posttest of Reading Comprehension}

An independent t-test is run to compare the mean scores of the experimental and control groups on the posttest of reading comprehension after the administration of the task-based 
writing and traditional writing.

Table 3 shows the descriptive statistics regarding the post-test of both groups.

Table 3. Post-test of reading comprehension by groups

\begin{tabular}{|lc|c|c|c|c|}
\hline & & & & & \\
Groups & & $\mathrm{N}$ & Mean & Std.Deviation & $\begin{array}{c}\text { Std. Error } \\
\text { Mean }\end{array}$ \\
\hline Post-test & Task-based Reading & 30 & 27.2000 & 5.36528 & .97956 \\
& Traditional Reading & 30 & 23.0000 & 7.76375 & 1.41746 \\
\hline
\end{tabular}

As displayed in table 3 the mean scores for the experimental and control groups on the posttest of reading comprehension are 27.20 and 23 .

Table 4 is related to the posttest of reading comprehension of both experimental group and control group.

Table 4. Independent t-test post-test of reading comprehension by groups

\begin{tabular}{|c|c|c|c|c|c|c|}
\hline \multirow{2}{*}{} & \multicolumn{2}{|c|}{$\begin{array}{c}\text { Levene's Test for } \\
\text { Equality of } \\
\text { Variances }\end{array}$} & \multicolumn{3}{|c|}{ t-test for Equality of Means } \\
\cline { 2 - 7 } & $\mathrm{F}$ & Sig. & $\mathrm{t}$ & Df & Sig. (2-tailed) & $\begin{array}{c}\text { Mean } \\
\text { Difference }\end{array}$ \\
\hline Post-test Equal variances assumed & 1.930 & .170 & 2.438 & 58 & .018 & 4.20000 \\
Equal variances not assumed & & & 2.438 & 51.555 & .018 & 4.20000 \\
\hline
\end{tabular}

The results of the independent $t$-test $(t=2.438)$ represents a strong effect size and indicates significant difference between the mean scores of the two groups on the posttest of reading comprehension. Thus it can be concluded that the null hypothesis as task-based writing is not more effective than traditional writing on the development of reading comprehension among EFL advanced Iranian learners is rejected. The subjects in the experimental group, after receiving task-based writing activities, significantly improved their reading comprehension.

It should be noted that the assumption of homogeneity of variances is met. As displayed in table 4 the Levene's F-value is not significant $(F=1.930)$. That is why the first row of table 4, i.e. "Equal variances assumed" is reported. 


\subsection{Discussion}

As the analyses indicated, participants in the first group (TBW) made significant progress in their post-test regarding reading comprehension. Therefore, the treatment had a positive effect on the performance of this group. This finding advocates what Bantis (2008) stated regarding task-based writing. He emphasized that task-based writing instruction can be a useful vehicle for differentiated instruction, constructivist pedagogy, and principles of second language acquisition to address the diverse needs of second language learners.

Task-based Writing (TBW) contributed significantly to the development of reading comprehension within groups. "Task-based teaching can be viewed as a new orthodox within contemporary ELT, falls within the general umbrella of communicative language teaching (CLT) and can be seen as an offshoot from it"'(Kumaravadivelu, 2006, cited in Carless, 2007, p. 595). Many studies carried out and literature written have been on the theoretical aspects and issues of task-based instruction. That is, task-based language teaching has come to be theoretically accepted as a new paradigm and method in the second and foreign language learning research. However, experimental research on this issue is still poor (Sanchez, 2004; Carless, 2007).

Research and observation have shown that there is a link between reading and writing. This link has been verified through the research of many researchers. Cognitive theorists believe that reading and writing share similar schema or structures. Much of the teaching and research suggest that the processes of reading and writing are mutually reinforcing and should even be taught together as a common base of meaning (Whyte, 1985). Specific research on how writing affects reading comprehension often focuses on the combination of sentences. Because vocabulary is integral to reading comprehension and writing reinforces what students understand orally. Paraphrasing and writing abstracts are also proven methods for increasing reading comprehension. Research on the writing process showed that peer conferencing entices students to get involved as readers and writers and that the decisions and awareness that grow from this process transfer to reading comprehension. Finally, reading comprehension is not only affected by writing, but also reading and writing mutually affect learning. Reading and writing should be contextually taught and learned, while research is required on the effects of writing on reading and reading on writing (Whyte, 1985).

The participants in this study also derived great satisfaction from task-based writing both because of its novelty and its inherent and unique characteristics. Hanaoka (2007) concludes that learners require intriguing topics to read, write, and talk about and writing lends itself to properly being used to meet these needs. Writing can be adopted and applied at all levels of proficiency. Moreover, there is an implicit consensus that writing paves the way for the development of a variety of tasks at intermediate through advanced learners.

In the literature regarding task-based instruction, there are paradoxical assumptions and theories on the issue of writing. Klapper (2003, cited in Carless, 2007) believes that task-based language teaching regards language acquisition as being too close to L1 processes to be applicable in EFL contexts. The link between task-based approaches and writing instruction has always been a matter of concern for teachers and this issue has cast doubts on 
the feasibility of task-based instruction (Carless, 2007).

\section{Conclusion}

A task-based lesson usually provides the learner with an active role in participating and creating the activities, and also increases their motivation for learning. A task-based lesson offers far more opportunities for the students to display their thinking through their actions. The teacher can also be more open to the needs of the students. TBL allows students to use the knowledge they have learnt and apply it productively in the task context (procedural knowledge). This practical experience helps learners appreciate why certain academic questions are important and provide an experiential substrate for the development of a further academic discourse (Buykkarci, 2010).

This study was intended to find out if traditional writing makes a significant contribution to the development of reading comprehension. It also concentrated on the usefulness of performing writing tasks on the development of reading comprehension. In the mean time, the means of scores of the students in the first group (task-based writing), before and after treatment (pretest and post-test), were compared against the means of scores gained by the participants in the second group (traditional writing) which functioned as control group. The results indicated the positive effect of task-based writing on reading comprehension.

\section{References}

Bantis, A. (2008). Using task-based writing instruction to provide differentiated instruction for English language learners. Unpublished MA thesis, University of Southern California, The Rossier School of Education. California. USA.

Benevides, M., \&Valvona, C. (2008). Task-based language teaching. [Online] Available: http://www.widgets-inc.com/downloads/download.php?fileName...tblt.pdf (April 15, 2013)

Bourke, J. M. (2006). Designing a topic-based syllabus for young learners. ELT Journal, 60, 279-286.

Buykkarci, K. (2010). A critical analysis of task-based learning. Kastamonu Eğitim Dergisi, 17, 313-320.

Byrne, D. (1986). Teaching oral English. Harlow: Longman

Cabral, M. (2003). Developing task-based writing with adolescent EFL students. [Online] Available: http://www.itesl.Org./Techniques/Cabral_task-based writing.html (February 17, 2013)

Carless, D. (2007). The Suitability of Task-based Approaches for Secondary Schools: Perspectives from Hong Kong. System, 35, 595-608. http://dx.doi.org/10.1016/j.system.2007.09.003

Carless, D. (2009). Revisiting the TBLT versus P-P-P debate: Voices from Hong Kong. Asian Journal of English Language Teaching, 19, 49-66.

Crookes, G. (1986). Towards a Validated Analysis of Scientific Text Structure. Applied 
Linguistics, 7, 57-70. http://dx.doi.org/10.1093/applin/7.1.57

Ellis, R. (1994). The study of second language acquisition. Oxford: OUP.

Ellis, R. (1997). Second language research and language teaching. Oxford: OUP.

Ellis, R. (2003). Task-based language learning and teaching. Oxford: OUP.

Fotos, S. (2002). Structure-based interactive tasks for the EFL grammar learner. In Hinkel, E., and Fotos, S (Eds.). New perspectives on grammar teaching in second language classrooms. New Jersey: Lawrence Erlbaum Associates, Publishers.

Graves, D., \& Hansen, J. (1983). The author's chair. Language Arts, 60(2), 176-183.

Gregg, L. W., \& Steinberg, E. R. (Eds.). (1980). Cognitive processes in writing. Hillsdale, NJ: Erlbaum.

Hanaoka, O. (2007). Output, Noticing, and Learning: An Investigation into the Role of Spontaneous Attention to Form in a Four-stage Writing Task. Language Teaching Research, 11, 459-479. http://dx.doi.org/10.1177/1362168807080963

Hinkel, E. (1994). Native and Nonnative Speakers' Pragmatic Interpretations of English Texts. TESOL Quarterly, 28, 353-376. http://dx.doi.org/10.2307/3587437

Hinkel, E. (2002). Second language writers' text: Linguistics and rhetorical feature. Mahwa: New Jersey.

Jeon, I. J., \& Hahn, J. W. (2009). Exploring EFL teachers' perceptions of task- based language teaching: A case study of Korean secondary school classroom practice. Asian EFL Journal, 8, 10-32.

Kess, J. E. (1992). Psycholingistics. Amsterdam : John Benjamins.

Krahnke, K. (1987). Approaches to syllabus design for foreign language teaching. NJ: Prentice Hall.

Langer, J. A. (1984). Levels of questioning: An alternative view, In R. Freedle (Ed.), Cognitive and linguistic analyses of standardized test performance.Norwood, NJ: Ablex.

Langer, J. A. (1986). Children reading and writing: Structures and strategies. Norwood, NJ: Ablex.

Langer, J. A., \& Falihan, S. (2000). Writing and reading relationships: Constructive tasks. Retrieved April 15, 2103 from http:/www.albany.edu/cela/ publication/article/writeread.htm.

Littlewood, W. (2004). The Task-based Approach: Some Questions and Suggestions. ELT Journal, 58, 319-326. http://dx.doi.org/10.1093/elt/58.4.319

Nahavandi, N., \& Mukundan, J. (2012). Task-based language Teaching from Teachers's Perspective. International Journal of Applied Linguistics \& English Literature, 1, 115-121. http://dx.doi.org/10.7575/ijalel.v.1n.6p.115 
Nunan, D. (1993). Task-based syllabus design: Selecting, grading and sequencing tasks. In Crookes, G., \& Gass, S (Eds.)., Tasks in integrating theory and practice (pp. 55-68). Clevedon, UK: Multilingual Matters.

Nunan, D. (2004). Task-based language teaching. Cambridge: CUP.

Paran, A. (1996). First certificate gold practice exams. Addison Wesley Longman Limited: England.

Richards, J. C., \& Rodgers, T. S. (2001). Approaches and methods in language teaching. Cambridge: Cambridge University Press.

Sanchez, A. (2004). The task-based approach in language teaching. International Journal of Language Studies, 4, 39-71.

Sato, R. (2010). Reconsidering the effectiveness and suitability of PPP and TBLT in the Japanese EFL classroom. JALT Journal, 32, 189-201.

Skehan, P. (1996). Second language acquisition research and task-based instruction. In J. Willis, \& D. Willis (Eds.). Challenge and change in language teaching (pp. 17-30). Oxford: Heinemann.

Skehan, P. (1998). A cognitive approach to language learning. Oxford: OUP.

Smith, F. (1983). Reading like a writer. Language Arts, 60(5), 58-567.

Tierney, R. J., \& Pearson, P. D. (1983). Toward a composing model of reading. Language Arts, 60(5), 568-580.

Tilfarioglu, F., \& Basaran, S. (2007). Enhancing reading comprehension through task-based writing activities. The Reading Matrix, 7, 134-172.

Whyte, S. (1985). The connection of writing to reading and its effect on reading comprehension. [Online] Available: http://eric.ed.gov/ERICWebPortal/search/detailmini.jsp?_nfpb=true\&EricxtSearch_SearchVal ue_0=ED278940 (May 4, 2013)

Willis, J. R. (2004). An overview of task-based instruction: From theories to practices. NW Washington: Georgetown University Press.

Wills, D., \& Willis, J. (2009). Task-based language learning: Some questions and answers. JALT Journal, 33, 3-8.

\section{Copyright Disclaimer}

Copyright reserved by the author(s).

This article is an open-access article distributed under the terms and conditions of the Creative Commons Attribution license (http://creativecommons.org/licenses/by/3.0/). 